\title{
UPAYA PENCEGAHAN DAN MEMINIMALKAN RISIKO DAN HAZARD DALAM ASUHAN KEPERAWATAN
}

\author{
Ananda Muthia Bahri Hasibuan \\ anandamuthiag3@gmail.com
}

\section{Latar Belakang}

Setiap tempat kerja selalu mempunyai risiko terjadinya kecelakaan terutama di Rumah Sakit, oleh karena itu diperlukannya upaya pencegahan dan meminimalkan risiko dan hazard di Rumah Sakit. Pengidentifikasian bahaya dan risiko kerja merupakan tahap awal yang harus diperhatikan oleh pihak Rumah Sakit. Tujuan dari penelitian ini adalah untuk mengetahui jenis bahaya, dan penilaian risiko berdasarkan sumber bahaya dan penilain risiko berdasarkan jenis bahaya nya.

Bekerja di rumah sakit dapat menimbulkan risiko tertular penyakit dari pasien. Risiko ini tidak hanya berpotensi bagi tenaga medis saja, namun juga terhadap tenaga non medis seperti petugas kebersihan. Saat bekerja risiko yang selalu dihadapi oleh petugas kebersihan adalah terpapar faktor biologi dan terpapar bahan kimia atau obat pembersih.

Pada hakekatnya Keselamatan dan Kesehatan Kerja (K3) merupakan suatu usaha untuk menciptakan perlindungan dan keamanan dari berbagai risiko kecelakaan dan bahaya, baik fisik, mental maupun emosional terhadap pekerja, perusahaan, masyarakat dan lingkungan. Disamping itu, keselamatan dan kesehatan kerja diharapkan dapat menciptakan kenyamanan kerja dan keselamatan kerja yang tinggi.

Kesehatan dan Keselamatan Kerja (K3) merupakan suatu upaya perlindungan kepada tenaga kerja dan orang lain yang memasuki tempat kerja terhadap bahaya dari kecelakaan kerja. Tujuan K3 yaitu untuk mencegah, mengurangi, bahkan menihilkan risiko penyakit dan kecelakaan akibat kerja (KAK) serta meningkatkan derajat kesehatan para pekerja sehingga produktivitas kerja meningkat.

Dalam Undang-Undang Republik Indonesia Nomor 36 Tahun 2009 Tentang Kesehatan, upaya kesehatan kerja ditunjukkan untuk melindungi pekerja agar hidup sehat dan terbebas dari gangguan kesehatan serta pengaruh buruk yang diakibatkan oleh pekerjaan sehingga sudah seharusnya pihak pengelola RS menerapkan upaya-upaya K3 di RS. K3 
termasuk sebagai salah satu standar pelayanan yang dinilai di dalam akreditasi RS, disamping standar pelayanan lainnya.

Pekerja RS mempunyai risiko lebih tinggi dibanding pekerja industri lain untuk terjadinya Penyakit Akibat Kerja (PAK) dan KAK, sehingga perlu dibuat standar perlindungan bagi pekerja yang ada di RS. Untuk mencegah dan mengurangi resiko bahaya tersebut maka perlu ditetapkan standar K3 di RS. Perlunya pelaksanaan K3RS mengenai kebijakan pemerintah tentang RS di Indonesia adalah untuk meningkatkan akses, keterjangkauan, dan kualitas pelayanan kesehatan yang aman diRS. Perencanaan, pelaksanaan, monitoring, dan evaluasi K3 RS serta tindak lanjut, yang merujuk pada SK Menkes No. 432/ Menkes/ SK/ IV/ 2007 tentang Pedoman Manajemen K3 di RS dan OHSAS 18001 tentang Standar Sistem Manajemen K3. Sistem manajemen K3RS adalah bagian dari sistem manajemen RS.

\section{METODE}

Melakukan obeservasi yang didasarkan atas literatur penelitian. Dijelaskan secara deskriptif. Berdasarkan literatur tersebut akan disesuaikan dengan judul jurnal ini yaitu upaya pencegahan dan meminimalkan risiko dan hazard di rumah sakit. Metode yang saya gunakan yaitu dengan menggunakan metode literatur review dengan pendekatan jurnal, buku dan ebook untuk mendapatkan data yang akurat mengenai perencanaan keperawatan dalam keluarga. Adapun jurnal atau artikel dan e-book yang digunakan pada literatur review adalah jurnal dan e-book yang didapatkan dengan menggunakan google scholar .

\section{HASIL}

Penilaian risiko adalah proses evaluasi risiko-risiko yang diakibatkan adanya bahayabahaya, dengan memperhatikan kecukupan pengendalian yang dimiliki, dan menentukan apakah risikonya dapat diterima atau tidak (PERMENAKER No.05 1996).

Menurut PERMENAKER No. 05/MEN/1996, pengendalian risiko kecelakaan dan penyakit akibat kerja dilakukan dengan berbagai macam metode, yaitu: 
1. Pengendalian teknis atau rekayasa yang meliputi eliminasi, substitusi, isolasi, ventilasi, higiene, dan sanitasi (engineering control).

2. Pendidikan dan pelatihan.

3. Pembangunan kesadaran dan motivasi yang meliputi sistem bonus, insentif, penghargaan, dan motivasi diri.

4. Evaluasi melalui internal audit, penyelidikan dan etiologi.

5. Penegakan hukum.

Berdasarkan National Safety Council mengatakan bahwa hazard adalah faktor-faktor intrinsik yang melekat pada sesuatu berupa barang atau kondisi dan mempunyai potensi menimbulkan efek kesehatan maupun keselamatan pekerja serta lingkungan yang memberikan dampak buruk. Sedangkan menurut Miles Nedved Hazard adalah suatu aktivitas atau sifat alamiah yang berpotensi menimbulkan kerusakan. Pengertian berdasarkan Frank Bird Jr, hazard adalah suatu kondisi atau tindakan yang dapat berpotensial menimbulkan kecelakaann dan kerugian (AS/NZS 4601 1999).

Berapa komponen yang menyangkut terhadap hazard:

1. Karakteristik material

2. Bentuk material

3. Hubungan pemajanan dna efek

4. Kondisi dan frekuensi penggunaan

5. Tingkah laku pekerja

Upaya yang dapat dilakukan oleh perawat untuk meminimalisirkan risiko dan hazard yang akan terjadi, yaitu:

1. Batasi akses ke tempat sosialisasi

2. Menggunakan APD dengan benar

3. SOP memasang APD, jangan ada sedikitpun bagian tubuh yang tidak tertutup dengan APD

4. Petugas diharapkan untuk tidak menyentuh bagian tubuh yang tidak tertutup APD

5. Membatasi sentuhan langsung ke pasien

6. Cuci tangan sebelum melakukan dan setelah melakukan tindakan

7. Melakukan pemeriksaan secara berkala kepada perawat

8. Hindari memegang benda yang mungkin terkontaminasi 


\section{PEMBAHASAN}

Keselamatan dan kesehatan kerja merupakan hal penting yang harus diterapkan di semua tempat kerja, baik pada sektor formal maupun sektor informal. Terlebih bagi tempat kerja yang memiliki risiko atau bahaya yang tinggi, serta dapat menimbulkan kecelakaan kerja maupun penyakit akibat kerja. keselamatan dan kesehatan kerja seharusnya diterapkan pada semua pihak yang terlibat dalam proses kerja, mulai dari tingkat manager sampai dengan karyawan biasa. Berdasarkan Undang-Undang No. 1 Tahun 1970 yang menyatakan bahwa setiap tenaga kerja memiliki hak untuk mendapat perlindungan bagi keselamatannya dalam melakukan pekerjaan untuk kesejahteraan hidup dan meningkatkan produksi serta produktivitas Nasional.

Berdasarkan undang-undang No. 44 Tahun 2009 tentang rumah sakit, menyatakan rumah sakit adalah institusi pelayanan kesehatan yang menyelenggarakan pelayanan kesehatan perorangan secara paripurna yang menyediakan pelayanan rawat inap, rawat jalan, dan gawat darurat. Karena merupakan suatu institusi yang bergerak dalam bidang pelayanan kesehatan, maka rumah sakit juga termasuk dalam kategori tempat kerja. Isi dalam pasal 23 undang-undang No. 23 Tahun 1992 tentang kesehatan menyatakan bahwa setiap tempat kerja wajib menyelenggarakan kesehatan kerja. Berdasarkan pernyataan tersebut, maka rumah sakit sebagai salah satu tempat kerja juga wajib untuk menyelenggarakan kesehatan kerja bagi para pekerjanya agar terhindar dari potensi bahaya yang ada di rumah sakit.

Asuhan keperawatan merupakan pedoman tertulis untuk perawatan klien. Rencana perawatan terorganisasi sehingga setiap perawat dapat dengan cepat mengidentifikasi tindakan perawatan yanng diberikan.

Risiko didefinisikan sebagai kombinasi dari kemungkinan terjadinya peristiwa yanng berhubungan dengan cidera parah, atau sakit akibat kerja atau terpaparnya seseorang atau alat pada suatau bahaya. Jadi, bahaya adalah sifat dari proses yang dapat merugikan individu, dan risiko adalah kemungkinan bahwa itu akan terjadi bersama dengan seberapa para akibat yang akan diterima. Tidak hanya risiko yang sering timbul dalam perencanaan asuhan keperawatan tapi bahaya atau lebih dikenal dengan hazard juga sering muncul pada perencanaan asuhan keperawatan akibat kurangnya perawat memperhatikan prinsip $\mathrm{K} 3$, pengertian hazard itu 
sendiri adalah suatu kondisi atau tindakan yang dapat berpotensial menimbulkan kecelakaan dan kerugian.

Beberapa risiko dan hazard yang timbul dalam asuhan keperawatan seperti kesalahan saat merencanakan pengkajin.

Upaya perawat yangn dapat dilakukan untuk mencegah dan meminimalkan risiko dan hazard dalam perencanaan asuhan keperawatan yaitu:

1. Identifikasi sumber bahaya, penilaian, dan pengendalian faktor risiko.

Mislanya pada rumah sakit harus melakukan pengkajian dan identifikasi sumber bahaya, penilaian serta pengendalian faktor risiko sebagai berikut:

a. Identifikasi sumber bahaya

Identifikasi sumber bahaya dapat dilakukan dengan mempertimbangkan:

1.) Kondisi dan kejadian yang dapat menimbulkan potensi bahaya

2.) Jenis kecelakaan dan PAK yang mungkin dapat terjadi

b. Penilaian faktor risiko

Merupakan proses untuk menentukan ada tidaknya risiko dengan jalan melakukan penilaian bahaya potensial yang menimbulkan risiko kesehatan dan keselamtan kerja

c. Pengendalian faktor risiko

Dilakukan melalui empat tingkatan pengendalian risiko yaitu menghilangkan budaya, emnggantikan sumber risiko dengan sarana/peralatan lain yang tingkat risiko nya lebih rendah/tidak ada (engineering/rekayasa), administrasi dan APD

2. Membuat peraturan

Rumah sakit harus membuat, menetapkan dan melaksanakan standar operasional prosedur (SOP) sesuai dengan peraturan, perundangan dan ketentuan mengenai K3 lainnya berlaku. SOP ini harus dievaluasi, diperbaharui dan harus dikomunikasikan serta disosialisasikan pada karyawan dan pihak yang terkait

3. Tujuan dan sasaran

Rumah sakit harus mempertimbangkan peraturan perundang-undangan, bahaya potensial, dan risiko K3 yang bisa diukur, satuan/indikator pengukuran, sasaran pencapaian dan jangka waktu pencapaian.

4. Indikator kinerja 
Indikator harus dapat diukur sebagai dasar penilaian kinerja K3 yang sekaligus merupakan informasi mengenai keberhasilan pencapaian SMK3 rumah sakit

5. Program kerja

Rumah sakit harus menetapkan dan melaksanakan program K3 rumah sakit, untuk mencapai sasaran harus ada monitoring, evaluasi dan dicatat serta dilaporkan

6. Pengorganisasian

Pelaksanaan K3 di rumah sakit sangat tergantung dari rasa tanggung jawab manajemen dan petugas terhadap tugas dan kewajiban masing-masing serta kerja sama dengan pelaksanaan K3.

Pelatihan K3 sangat penting bagi pekerja terutama bagi pekerja yang tidak mempunyai dasar pengetahuan tentang $\mathrm{K} 3$ dan bekerja di lingkungan kerja dengan risiko atau bahaya yang tinggi. Pelatihan ini bertujuan untuk memberikan pengetahuan tentang K3, yang nantinya akan dapat diterapkan oleh petugas kebersihan di tempat kerja, sehingga mereka dapat lebih berhati-hati dalam bekerja. Menurut Murti, (2010) Sebuah penelitian hubungan antara pelatihan keselamatan dan kesehatan kerja dengan perilaku aman pada pekerja konstruksi menyatakan bahwa terdapat korelasi positif dan hubungan yang signifikan antara skor pelatihan K3 dengan perilaku aman pada pekerja konstruksi. Jadi petugas kebersihan yang sudah mengikuti pelatihan K3 akan memiliki kecenderungan untuk mengubah perilaku mereka menjadi lebih aman saat bekerja.

Untuk mencegah terjadinya kecelakaan atau penyakit akibat kerja adalah melakukan pengendalian terhadap risiko tersebut. Pengendalian yang sudah dilakukan oleh pihak perusahaan adalah menyediakan alat pelindung diri berupa masker, sarung tangan, dan sepatu boot. Penggunaan APD memang sering di pilih sebagai pengendalian bahaya untuk mengurangi atau mencegah terjadinya kecelakaan kerja ataupun penyakit akibat kerja. Hasil penelitian tentang pengaruh pemakaian APD terhadap kejadian kecelakaan kerja menunjukkan bahwa kepatuhan atau selalu menggunakan APD dapat membuat angka kejadian kecelakaan kerja semakin rendah. (Anggraini, 2011) Selain itu perusahaan juga melakukan pelatihan tentang housekeeping maupun K3 bagi petugas kebersihan.

Pihak rumah sakit telah memberikan himbauan atau pemberitahuan untuk tetap menjaga kebersihan kesehatan diri saat bekerja, seperti mencuci tangan sebelum dan sesudah bekerja. Tindakan mencuci tangan sebelum dan sesudah bekerja sangatlah penting bagi pekerja yang bekerja di rumah sakit hal ini dapat menurunkan kejadian infeksi atau penularan 
penyakit. Hasil penelitian tentang hubungan pelaksanaan tindakan cuci tangan perawat dengan kejadian infeksi di rumah sakit menyatakan bahwa terdapat hubungan yang bermakna antara pelaksanaan cuci tangan dengan kejadian infeksi. (Alfred. 2010) Selain itu rumah sakit juga mengadakan pelatihan pada pekerjanya termasuk petugas kebersihan boleh mengikuti pelatihan yang biasa dilakukan rumah sakit adalah pelatihan APAR dan tentang bantuan hidup dasar.

Pengendalian yang dilakukan untuk mencegah atau mengendalikan risiko yang ada sebenarnya sudah cukup baik dengan menyediakan alat pelindung diri, membekali pekerjanya dengan pelatihan, dan memberikan himbauan atau peringatan untuk selalu menjaga kebersihan dan kesehatan diri. Namun masih terjadinya kecelakaan kecil seperti tergores kaca atau steinless pada petugas kebersihan dapat diakibatkan karena kurang berhatihati dalam bekerja dapat juga terjadi karena jenis alat pelindung yang kurang pas untuk pekerjaan tersebut. Oleh karena itu perlu dilakukan peningkatan kesadaran diri pada petugas kebersihan dalam menjaga keselamatan dan kesehatan saat bekerja. Hal itu dapat dilakukan dengan cara:

1. Pemberian reward bagi pekerja yang selalu bekerja dengan baik dan mentaati peraturan yang ada serta memberikan punishment berupa teguran kepada pekerja yang tidak mematuhi peraturan saat bekerja. Diharapkan dengan adanya hal seperti itu dapat meningkatkan kesadaran petugas kebersihan, dan dapat meningkatkan produktivitasnya dalam bekerja.

2. Selain itu juga dapat dilakukan evaluasi mengenai penyediaan alat pelindung diri. Yaitu melakukan evaluasi mengenai jenis alat pelindung diri yang cocok untuk setiap kegiatan yang dilakukan petugas kebersihan misalnya sarung tangan yang digunakan saat membersihkan kaca atau pintu yang dibingkai steinless sebaiknya menggunakan sarung tangan yang berbahan tebal dan tidak mudah sobek (bukan sarung tangan latek). Karena sebelumnya belum pernah dilakukan evaluasi terkait alat pelindung diri yang tepat untuk setiap kegiatan kerja yang dilakukan oleh petugas kebersihan.

\section{KESIMPULAN}

Keselamatan dan kesehatan kerja merupakan hal penting yang harus diterapkan di semua tempat kerja, baik pada sektor formal maupun sektor informal. Terlebih bagi tempat 
kerja yang memiliki risiko atau bahaya yang tinggi, serta dapat menimbulkan kecelakaan kerja maupun penyakit akibat kerja.

Asuhan keperawatan merupakan pedoman tertulis untuk perawatan klien. Rencana perawatan terorganisasi sehingga setiap perawat dapat dengan cepat mengidentifikasi tindakan perawatan yanng diberikan.

Upaya perawat yangn dapat dilakukan untuk mencegah dan meminimalkan risiko dan hazard dalam perencanaan asuhan keperawatan yaitu:

1. Identifikasi sumber bahaya, penilaian, dan pengendalian faktor risiko.

2. Membuat peraturan

3. Tujuan dan sasaran

4. Indikator kinerja

5. Program kerja

6. Pengorganisasian

\section{DAFTAR PUSTAKA}

Fathi, A., \& Simamora, R. H. (2019, March). Investigating nurses' coping strategies in their workplace as an indicator of quality of nurses' life in Indonesia: a preliminary study. In IOP conference series: Earth and Environmental science (Vol. 248, No. 1, p. 012031). IOP Publishing.

https://stikesypib.ac.id/blog/upaya-mencegah-dan-meminimalkan-risiko-dan-hazard/

Iftadi, I., Jauhari, W.A., dkk. 2011. Penentuan Faktor-Faktor Bahaya yang Dihadapi Perawat di RSUD Kabupaten Karanganyar dan Usulan Pencegahannya Menggunakan Metode AHP. Performa (2011) Vol. 10, No.1: 1 - 10

Indragiri, S., \& Yuttya, T. 2018. MANAJEMEN RISIKO K3 MENGGUNAKAN HAZARD IDENTIFICATION RISK ASSESSMENT AND RISK CONTROL (HIRARC). JURNAL KESEHATAN Vol. 9 No. 1

Ivana, A., Widjasena, B., dkk. Analisa Komitmen Manajemen Rumah Sakit (RS) Terhadap Keselamatan Dan Kesehatan Kerja (K3) Pada RS Prima Medika Pemalang. JURNAL KESEHATAN MASYARAKAT (e-Journal), Volume 2, Nomor 1. 
Kumayas, Putri, Elshadai., Kawatu, Paul, A.T., Warouw, Finny. (2019) . Hubungan Pengetahuan dan Sikap Dengan Penerapan Kesehatan dan Keselamatan Kerja (K3) Pada Perawat di Rumah Sakit Bhayangkara TK III Manado. Jurnal KESMAS, 8(7).

Ningrum, S.S., \& Tualeka, A.R. 2018. UPAYA PENGENDALIAN RISIKO PADA UNIT PENGELOLAAN LIMBAH MEDIS BENDA TAJAM DI RUMAH SAKIT. JPH RECODE Maret 2018; 1 (2) : 98-108.

Pertiwi, \& Nurhantari, Y., dkk. 2019. Hazard identification, risk assesment and risk control serta penerapan risk mapping pada Rumah Sakit Hewan Prof. Soeparwi Universitas Gadjah Mada. Berita Kedokteran Masyarakat, Volume 35 No. 2.

Prasetio, D.B., Hasanbasri, M., dkk. 2015. RISIKO BAHAYA ERGONOMI PETUGAS KEBERSIHAN OUTSOURCING DI RUMAH SAKIT UMUM DAERAH SLEMAN. $J$. Kesehat. Masy. Indones. 10(1): 2015 ISSN 1693-3443

Putri, Sentya., Santoso., Rahayu, Endang, Purnawati. (2018) . Pelaksanaan Keselamatan dan Kesehatan Kerja Terhadap Kejadian Kecelakaan Kerja Perawat Rumah Sakit. Jurnal Endurance, 3(2).

Simamora, R. H. (2020). Learning of Patient Identification in Patient Safety Programs Through Clinical Preceptor Models. Medico Legal Update, 20(3), 553-556.

Yuantari, M.G.C, \& Nadia, H. 2018. Analisis Risiko Keselamatan dan Kesehatan Kerja Pada Petugas Kebersihan di Rumah Sakit. Faletehan Health Journal,5 (3) (2018) 107-116. 